\title{
Analysis of James Joyce short stories
}

\section{Amir Daneshzadeh}

\author{
E-mail address: amir_daneshzadeh1347@yahoo.com
}

\section{Keywords: analysis; short stories; James Joyce}

\begin{abstract}
Collection of short stories of James Joyce in a book under the title of "Dubliners" (1914) is a collection composing of 15 short stories, which topic of all of them is living in Dublin (stories about death, love, live in school, etc.). Short story of "sisters" narrates feelings of a boy about death of a priest. The first woman, who is afraid of love, a mother in law speaks about ambition and destroys her daughter. It ispainful narrative of a single man, who leaves the woman he loves and the woman finds in the time of her death that he has been in his loneliness all his life. Accordingly, it could be mentioned that the author has selected in his short stories a style that Flober has been its establisher. Hence, stories in the collection of Dubliners have been strongly image-based and have been less relied on storied actions. (Stein et al, 2008)

The present study has analyzed two short stories of the mentioned collection under the titles of "The Dead Persons" and "The sisters $\backslash \mathrm{s}$ ". In this analysis, the author has considered internal modes and feelings of characters of the story. Process of analyzing the two works has been firstly related to analysis of every story separately and then has been related to goals and destinies of creator of the work and totally his collection of short stories. Finally, the study has considered investigation and analysis of short stories of James Joyce, which analysts and critics of his works have presented it and it is that Dubliners should be considered as an origin and generality. Considering stories of this artist separately can't be a competent work, since as it is obvious in this collection, the author has been tended to achieve a specific goal through considering a certain order for these stories.
\end{abstract}

\section{INTRODUCTION}

Stories of Joyce usually mix relatively unintegrated elements such as poetic mysticism and naturalism; elegant imagination and considering intonation and rhythm; extreme paltriness, and pervasive compassion.

In his works, Joyce has applied usually irony of situation, and reference to holly books and mythology. Specific view of Joyce to words and language as component cells of body of the story is so deep and innovative that still critics are searching for exploration of ambiguous layers of the story. Those parts have been hidden beyond new developed and innovated words by Joyce. Hence, a work like "Olli's", such as religious books, has several interpretations and hence, there are two completely opposite ideas about Joyce. Some people believe that he is a mad and la-di-da person, which his involvement with language has conducted him towards trackless way. Others believe that he is a unique skillful person, who has gone beyond the senses of today's people. (Ahmadian et al, 2010)

Innovation of Joyce is originated in his extraordinary language. He has not only recovered old words of his language, but also he has created new words in his works. His words are a large number of words and letters that can form a single word, so that a multiple sense and feeling can be created.

"Dubliners" is collection of short stories of James Joyce (1882-1941) an Irish author, which have been published in 1914. It has been the first book, which introduced him to people after publishing his youth age poems under the title of "parliamentary poems" (1907).Joyce has become famous with his short stories that have been written while he was living in Trist City. The author in his stories has introduced several cases of Dublin's people and has also considered some conventional aspects of human nature for them. Literal position of Joyce is clearly realism; although the psychological realism can be appeared through exact analysis of internal world of human. Additionally, in this book Joycehas introduced himself as one of the deepest viewers of life of 
contemporary Bourgeoisies of his age. Some of his stories have made clear non-remediable of challenging status, which Irish community used to live in. in all of his works, he has clearly considered painful conditions of Irish people through using irony of situation and suspense. However, in this book this hidden unhappiness has been presented more clearly and honestly. (Joyce, 1968)

Booker (1996) has also written that works of Joyce, especially his coaction of short stories and initial novels, can be analyzed from different dimensions. He has used idea of "inter-textual" and also discourse analysis of Bakhtin to show relationship between content of Joyce's works and other pioneers of the literature fromHomer and Dostoyevsky. Booker has introduced Joyce as a "Colonialist" author because of his opposition to culture of Britain. He has also stated that analysis of his works can be considered even in line with works of colonialist and American-African authors. (Ahmadian et al, 2010)

\section{DISCUSSION AND RESULTS}

\section{The dead}

The most beautiful story among 15 stories in "Dubliners" is "The Dead". Joyce has collected all things of his previous stories and represented them again. The story starts from a party and the readers should be careful not to miss a single scene and word. Everything happens simply in a party. The party has no strange and unusual event in it. All gusts dance, drink, eat dinner, and speak to each other. So, what is special in this story? This is the point that Joyce has considered and has had more kindly behavior to his audiences. At the end moments of the story, gusts go back to their homes and Gabriel goes also to hotel with his wife. They speak to each other on the way and when his wife speaks about some memories for the first time, her words make Gabriel hardly tumbled. Everything destroys in his mind and even looks at his wife as they have never been couples. Here, the veils remove from the truth for Gabriel and readers, so that Gabriel can understand secrets of his life and also people can understand the story of "The Dead". Here, the things are clearer and it is the time to remove veils and understand all ambiguous things that have made readers to be in challenge.

"Oh yes! Newspapers were right: snow had covered all Ireland; in all dark points of central plain, on treeless hills and then had fallen on western pints of "Bug o Allen" and on dark and sharp entry of the river"

"Listening to fall of snow from the sky like final falling of lives and dead persons, Gabriel became witless."

This snow had a lot of discussions and narratives hidden in it for many years. Who knows that what is the snow?

"The Dead" is the last text of the collection "Dubliners" written by James Joyce in 1914. The story is considered typically a kind of modernist-classic text and has been written in a period that has also included 3 other works of Joyce later.

The said story has become a classic work because of many reasons and technique of narration is surely one of the mentioned reasons. Here, analytical evaluation of this story would be considered. Priority of the story to others is in this issue that its content is relatively understandable and available. Another necessary issue is that John Histone has cleared some features and narrative issues of the story indirectly. (Walzl, 1996)

The story starts in a party in a light and happy house at the midnight and while fall of snow. Description of scenes that are signs for life and death and more importantly presence of "death" are observable in this story.

According to Gabriel: "3 deadly hours are required for wearing clothes. Aunts say that Greta should be destroyed lively."

In other words, it is an Irish irony that refers to life and death. Many times, warmness and happiness provide conditions for love and marriage; although every event can destroy it. At the beginning of the story, Gabriel says to Lily daughter of servant that as soon as possible they will participate in his wedding party. However, Lily answers bitterly: "today's men lie about everything and want to explore something in women." 
Following, such opposite signs would be observed a lot, where people are in contrary to culture of coastal part of Ireland or traditional and urban residents of western part of the city. In the party, western Dubliners are moderate, that their discussions and behaviors are hollow and deadhead. (The author writes just critical papers instead of writing creative works and more importantly, behavior of gusts would be limited to drinking, eating, and listening to meaningless music and even the piano music has been said as a hollow drum). Opposite to characters like Miss Aiors, coworker of Gabriel, and his wife Greta and even his wife's lover that are related to the west, others are honest, happy, and intimate people. Julia Aunt is skillful in singing; although she is very old and dotard.

In a few scenes that symbols have been applied in right position, scene of departure of gusts can be mentioned. At this part, gusts are talking about snow and coldness to provide symbol of death. One gust speaks about hard coldness and that all people will catch a cold. Others are also trembling from coldness. Consider some sentences as follows:

Kate aunt: "everyone has caught a cold"

Merry Jin: "everyone says that such snow fall has not been existed for past 30 years"

While saying goodbye, suddenly some sentences would be stated that they are repeated for more than ten times. "Goodnight, have a good night; goodnight to everyone; goodnight; and again goodnight"

Some irony is hidden in these sentences, an ironic picture to provide end of the story, which refers to death.

Reflection of images in the mirror refers to mendacious self-captivation and also a symbol of virtual character, which showsfactitive self-confidence. At this story, Gabriel is hardly selfcaptivated. His self-captivation has been created in view of others, aunts, gusts, and servants.

Joyce follows the story through showing self-captivation referring to eyes and glasses of Gabriel. His small and restless eyes stare on bright and flat surface of the room. In other words, dazzling brightness of the area results in his self-captivation and prevents his conscious view to the world. However, Joyce makes Greta to look in the mirror in the most beautiful part of the Gabriel's story. The thing that Greta sees is not clear at the first, since she turns back with a serious and depressed face. (Elman, 1958)

However, Gabriel sees his unreal and virtual character in the mirror. While passing against wall mirror he sees his body and vast chest, his face that he was stared to it while looking in the mirror and also he looks to his golden frame glasses.

Greta answers: "he was working in a factory"

Gabriel continues his efforts, while he is trying to have a patiently expression and says: "Greta! What caused death of the young man? Whether he was suffering from cholera?" The wife becomes silent after hearing his words and states that "I think he was died for me".

There is an elegant ambiguity in this answer, which confirms self-orientation of love and fights against reasonable question of Gabriel unconsciously.

Memories of dead lover makes Greta free of feelings, so she let his husband kiss her with no feelings. Maybe memories of the dead lover are still alive. Her words make a fire in his husband. On the other hand, Gabriel makes other issues also in his mind like his conflict with Miss Evers that he asked her to have national identity and spend his holiday in south of Ireland (the place of her date with the dead lover). Everything tries to make Gabriel blind. He looks outside from the window that one time in his mind his competitor was stood. He thinks that he has died because of being in love with Greta. Michel has died for Greta's love. So, he becomes jealous because of his elf-devotion for loving a woman.

Now they are in a love triangle and are competitors for each other. Imaginary facing of Gabriel with Michel creates contradictory mode; a dead lover, who is stood in the rain outside and is happy for the moment of joining; and other ones is living husband, who watches snow fall in his unhappiness in a dark room of hotel. In this scene, window changes to a symbolic reflective mirror and displays real vision. In other words, Joycemakes two lovers to seek for woman's love at the 
midnight. However, living husband is like a moving dead person and the dead lover seems to be alive.

Gabriel finds that he has not experienced love in life like Michel and following it finds that he has been deprived from the life blessing. Then, he tries to ignore self-captivation that he received from people in the party and create love and patience in his heart for his wife, so that the compassion can connect his to his wife like a thin chain. The chain is not love, since they have passed from boundary of youth and prettiness and happiness. So, at this step he comes out of his self-captivation and pride and achieves identification of his own and compassion with others.

After that, Gabriel feels join to dead lover of his wife, meaning to a lamb burned in love altar of his wife. He becomes slowly submitted with the dead lover and becomes interested in his emotions, a domain that is out of his senses. He thinks, it is better to die for love and with no fear than ding as a result of oldness and losing happiness and youth. At the end, his feelings are not hate, but also he feels compassion and victimizes himself to become aware of sad unity of live and dead persons. (Loath, 1996)

\section{Short story of "Sisters"}

"The sisters," the first of the stories in Dubliners, is also one of the more accomplished tales. Subtle, haunting, and beautifully controlled, "The sisters" is also elusive, withholding from us the extent of the understanding possessed by the nameless boy narrator.

In his 3 first stories, Joyce has designed characters in the position of motivational evaluation. "The sisters", "An Encounter" and "Araby" are three short stories that are specific searches of sensitive Dubliner youths. These youths make themselves far from pest of deviated environment. These persons are not involved in adult-leg and they are submitted in their minds. From the first, they appear in position of judges of Dublin, since its criteria have not been solved in acidic solution of corruption of Dubliners. Hence, the story and achieving story of "The Dead", judgment of reader would be formed on this basis that characters are strongly weak in impartial judgment about the story.

We learn soon what old Cotter is referring to: Father Flynn, the narrator's friend, is dead. The narrator's uncle mentions that Father Flynn was a great friend of the narrator; he'd taken the boy under his wing, and may have had some idea that the boy would become a priest one day. Old Cotter and the uncle discuss this friendship. Old Cotter seems to disapprove, as he thinks adults should "let a young lad run about and play with young lads of his own age" (2). The narrator is silent, but furious that old Cotter is referring to him as a child.The narrator keeps seeing the old priest's paralyzed face. As he wanders between waking and sleep, the face follows him, lips moving as if he is confessing something.

The priest used to teach him about history and Catholic doctrine. The narrator finds he lacks the courage to knock on the door and go in to look at the body. The boy tries to mourn, but feels he can't. School is out, and the boy cannot help but feel a sense of freedom, even in the priest's death. He's annoyed at himself for this feeling: the priest taught him many things, about history and Latin and the ceremonies and vestments of the priesthood.One night, when he was needed to go on a call, he couldn't be found. They found him in a confessional booth, laughing to him. That's when they thought something might be wrong with him.

In this story, after the priest Father Flynn dies, a young boy who was close to him and his family deal with his death superficially. The young nameless narrator speaks of his friend, a man who has had his third stroke. The young narrator passes by his friend's window every day, waiting for the day when he will see two candles in the dark: the sign that his friend has passed away, for two candles are put at the head of a corpse. For some time, the narrator's friend has been paralyzed. The word has a strange sound to the narrator. In fact, peak point of the story is based on such cognition.

Some scholars have identified the priest's mental illness as the final stages of syphilis, a sexually transmitted disease. If so, the sins of the priest's past would also seem to strip him of any special or holy status. Remember that the mad priest is found in the confessional, where Catholics go to confess their sins; the location suggests that the mental illness could indeed be the final 
product of a past sexual transgression. The narrator's mother asks if he received Extreme Unction, a final sacrament. For her to even ask the question suggests some kind of wrongdoing on Father Flynn's part; under only the most extreme of circumstances would the Church deny the sacrament to a priest.

Both the priest's madness and his hinted-at past sin reveal a world apart from his life as the official of his Church. His official functions as caretaker of the Church, and his unofficial function as the narrator's avuncular spiritual guide, were once the only sides of Father Flynn that the narrator saw. But his madness and possible dark past are now revealed to the narrator, all while the narrator is having what is presumably his first intimate experience with death.

The mad priest also has clear symbolic resonance, suggesting that the Church itself has become a senile and raving institution, with a dark past that has yet to be answered for. The degeneration of the priest's mind seems a metaphor for the deterioration of Catholic theology and doctrine. What once seemed a rational and coherent system has turned into gibberish in the priest's mind; metaphorically, Catholic philosophy has changed from a respectable approach to the pursuit of knowledge into an irrelevant and esoteric system of thought referring only to itself. The degeneration is seen in other aspects of Catholic life: Catholics of this period were perceived as being ridiculously superstitious, and in this story all the supposedly rational doctrines of the Church are thrust aside by Father Flynn's sister in favor of good-old fashioned fearful superstition. Rather than seek a rational explanation for her brother's madness, she resorts to superstition: his madness began, she claims, when he accidentally broke a holy chalice used during Mass.

Joyce extracts a complicated psychic action from this simple structure, an action that has been embedded in hero and distorted face of the priest. He provides the domain for other short stories and provides a style and meaning that can be found even in novels of Joyce.

Readers in order to configure final goal of the little boy, should consider spiritual and internal senses of the priest, along with the boy.The boy tries to mourn, but feels he can't. School is out, and the boy cannot help but feel a sense of freedom, even in the priest's death. He's annoyed at himself for this feeling: the priest taught him many things, about history and Latin and the ceremonies and vestments of the priesthood. Clearly, Joyce has more general idea that encompasses relation of Dubliners with church authorities. However, here the study tends to consider determining searches of boy for certain benefit and also evaluate this exploration with his personal involvement with the priest. (Colloney, 1965)

The narrator is oblique and difficult, beginning the story with a degree of openness but withdrawing gradually from the story. We are permitted to see something of his growth: for example, he fails to grieve deeply for his friend, and he is sensitive enough to know that he should. $\mathrm{He}$ is annoyed by this shortcoming, and in this annoyance we see a boy measuring him against what he knows is expected of him in this new experience. His dreams also show how the experience has shaken him: he sees his priest friend moving his lips, as if to confess something. This strange dream suggests that at least some part of the boy suspects his friend's past.The boy doesn't become free from imaginary picture of the priest even after his death. At the end, his role would be replaced by character of the priest and he becomes involved in a corruption, in which the old man has been involved previously.

Force faithfulness of the boy to search for vain issue makes him to have an impartial viewer role. The initial mode is resulted from his dual character. On one hand, expressing feelings in adolescence and on the other hand his love and emotion for priest makes him to behave against adults with a holy calmness.

Faithfulness of the boy to a deviated relationship with the priest would become clearer when personality of the priest and his relationship with the bot is analyzed. Clearly, appearance of the priest indicates total quality of Dublin City.

The topic of falling of priest in the place of admission refers to final deficit of his commitments. Afterwards, paralyzed thoughts make priest to ignore his thoughts about the life and at the last days of his life he becomes hopeful to his relations with the boy. The relationship provides the domain for him to achieve his desires. 
The boy finds his relation with the priest so complicated that believes that he can have no action. This belief to action is clearly in relation with church and indicates spiritual paralysis. (Magalner, 1956)

The boy seeks for a good friend. However, his relationship with the priest destroys it and deprives him from humanitarian characteristics. The priest wastes his mind, since trainings of the priest makes minds of students to a paralyzing suspense. The main objective of Joyce in this story is making his compatriots free from captivation of self- annoyance and annoying others. Hence he has written in a letter to Richards as follows: "I think that I have moved towards the first step of providing spiritual freedom of my country.

But towards the end of the story, we see less of the character's interpretive thoughts about his situation. It is as if the boy cannot quite put his finger on what has happened, in part because he's too busy trying to relate the bare facts. By the story's end, the narrative has the detachment of a story written in third-person. This removal of subjective opinions and feelings has the effect of pushing the priest and his story front-and-center in the reader's attention. The increasing detachment also suggests a boy still trying to make sense of what he has seen; the reader is invited to make sense of things, as the boy does, alone. The final frightening images of the mad priest are given directly from his sister's mouth, with no intrusive narrator to filter these events.

Joyce was clearly fascinated by the awesome spiritual power invested by the Catholic Church in its priests. Priests are the bearers of incredible spiritual responsibility. The Church holds that through the priest as an intermediary, sin it is atoned for. They are caretakers of men's souls, and masters of the many obscure and esoteric details of Catholic theology. But the mental decline of this priest has made him appear completely human and vulnerable. His mind, once the repository of knowledge about countless points of doctrine and ritual, has fallen into ruins.

The sisters are simple, good, poor, and humble, but their explanation for their brother's illness is self-deluding and irrational. In them and the impressionable young narrator, Joyce depicts an Ireland in the yoke of a tyranny that is mental rather than political. Paralysis is a recurring theme in the stories. The priest spends his last days paralyzed, and this sickness can be read a metaphor for the backwardness and reactionary politics of the Catholic Church.

The style of Joyce is applying hidden searches through combining elements and this is his evaluation and analysis of the story. "Angry and old face of paralyzed man" has covered all scenes of the story. The face is the most frightening picture of searching. The boy finds this face as the most frightening image. In the world of his imaginations, he tries at the time of sleeping to remove the angry and old face and think about Christmas; although he is not successful. Sudden spiritual appearance would be created in the reader, when he evaluates imagination power in this story. At the end when Lisa states that "When people looked at him, they found that he is suspicious", readers find that the basic problem has been related to people of Dublin, which have always diverse images. The study has also analyzed life of Dubliners. The study has exactly considered Joyce's mirror and found that there is a problem with this issue. (Brand bore, 1996)

\section{ANALYSIS OF THEMES OF TWO STORIES}

This is not a new thought that structure of short stories of James Joyce, which were considered episodic and unintegrated one time, is unit and integrated. High order $\mathrm{f}$ its boundary structure refers perfect continuity of stories. The structure refers to elegance of Joyce's style in his old age. As he states in his short stories, each of his short stories is a season of ethical history of his country and states that Dublin is focus point of "paralysis point" and this point of view has affected his novels later. Many critics and analysts believe that ordered application of codes have been clear in naturalist body of the two stories in this study. Also, the relationship among the elements is apparently separation of the stories. For example, description of story "The Dead" has made it clear that silence of snow sculptures turns back to spiritual feelings of Gabriel, who turns back to ice windows at the end of the story and also deadly silence of paralyzed priest is similar to it. Such images that have been ordered meaningfully can make two stories stable and pave the way for appearance of these stories as a unit generality. However, every story is independent from others in 
terms of realism and can provide a perfect structure for their own. In both stories, symbolic paralysis that Joyce has referred to it makes the concept of movement more complicated. This paralysis is a silence that has been imposed as a result of lack of motivation and power internally and there has been no external factor involved. It seems that ethical paralysis has been presented directly in terms of physical silence even in real paralysis. Clear example of this issue is quality of feelings of the boy in "The Sisters". He achieves no destination as a result of constant influence of his teacher and at the same time, he hates from urban life and has the dream to travel a country in the east.

Alternative elements in the space of the two stories from the beginning to the end find a clear view and determine that the actual objectives are not available. At this story, sisters of the priest beak a glass and he becomes paralyzed and dies. He can't pour the vine in the mouths of good people and at the moment of his death puts an empty glass on his chest. In "The Dead", a table with drinks and foods on it indicates this issue that he has a vine that can empower his body and spirit, so that he can find love and make it a medicine on his loneliness pain.

In both stories, pictures such as coffin, place of admission, room, city, and surrounding areas would become mysterious when they refer to gorge. Repetition of these pictures makes them conventional secrets from the beginning. The images indicate generally limitation and silence of living in Ireland. (Ghiselin, 1956)

\section{CONCLUSION}

Usually, the objective of comparative studies in literal works is finding artistic similarities and commonness between two works, which have been analyzed in different periods of time and through using thoughts and life of the author, from different dimensions. It has been less observed that historical and psychological similarities of artist can be considered beside other artistic similarities. It seems that artistic work has a direct relationship with mind and spirit of the artists and their historical and social conditions. In fact, it could be mentioned that a literal and artistic work can be resulted from mental, psychological, historical, and social factors of artist's country. Accordingly, literal similarities of James Joyce in two short stories "The Sisters" and "The Dead" are probably resulted from psychological similarities and even similarities of characters in the stories. (Safarian et al, (1993)

Joyce has recovered one of the most challenging styles of narration in his stories. Language of Joyce in his stories is in a manner that destroys the time. Words are in an ambiguous form and would interfere to each other. Citations are also in an unintegrated form and also wide expanded loaning words are also evident in his stories.

Joyce in some cases applies extra details in his works and makes his writing as a surface work. In these cases, the chain that should connect subjects to each other becomes so this that can't be distinguished easily and even faces readers of short stories to problems. In this regard, presence of phrases that readers can't understand them can increase problems with this issue.

Fluid Flow of the Mind, which has been appeared in Joyce's works, clearly is a symbolic language for mental and psychological explorations and also utilization of mental images of author in order to create story from common samples in two stories from collection of James Joyce. Comparative study of these similarities makes conscious audiences to think about psychological and mental domains, social and historical conditions, and also similar spatial and temporal elements as a result of unstable and similar style between the two stories. 


\section{References}

[1] AhmadianMosa, Kashani Mohammad Mahdi, (2010), mystic aesthetics of art in face of man in work of James Joyce "youth", study of contemporary literature of the world, No.58, pp.4366

[2] Joyce James, (1967), Dubliners, trans. ParvizDarush, first edition, Tehran: pub. Asatir

[3] Joyce James, (1993), Dubliners and its analysis, trans. Mohammad-alisafarian and SalehHosseini

[4] Horn Stein Pressi and Broun, (2008), James Joyce (1882-1941), perception of culture of literature of the world, trans. Homayoun Nor Ahmar, art and architecture; scene, new period, No. 64 and 65

[5] YaqubLotte, (2003), "The Dead" of Joyce and "The Dead" of Hyosten, pub. Farabi, 14th edition, No.4

[6] Baker, J. R. (1962). Ibsen, Joyce, and the Living-Dead: A Study of Dubliners. Marvin Magalaner (Carbondale, 111., 1962), 19-32

[7] Benstock, B. (1966). "The Sisters" and the Critics. James Joyce Quarterly, 4(1), 32-35

[8] Bierman, R. (1966). Structural Elements in" The Dead". James Joyce Quarterly, 4(1), 42-45

[9] Connolly, T. E. (1965). Joyce's" The Sisters": a pennyworth of snuff. College English, 189195

[10] Loath, Jakob (1998), Narrative in Fiction Film; An Introduction, Oxford UP

[11] Ellmann, R. (1958). The Backgrounds of" The Dead". Kenyon Review, 507-528

[12] Walzl, F. L. (1966). Gabriel and Michael: The Conclusion of" The Dead ". James Joyce Quarterly, 4(1), 17-31

[13] Magalaner, M., \&Kain, R. M. (1956). Joyce: The man, the work, the reputation. New York: New York University Press

[14] Ghiselin, B. (1956). The Unity of Joyce's Dubliners. Accent, 16(2), 75 